Таня Маджарова

sulamittania@abv.bg

\title{
Силата на женското слово в баладите на К.Я. Ербен
}

\begin{abstract}
Madžarova Tanja, Silata na ženskoto slovo v baladite na K.J. Erben (The Power of Women's Words in K.J. Erben's Ballads). „Poznańskie Studia Slawistyczne” 4. Poznań 2013. Adam Mickiewicz University Press, pp. 103-112. ISBN 978-83-232-2525-6. ISSN 2084-3011.
\end{abstract}

The power of women's words in K.J. Erben's ballads discusses the author's literary texts (the collections Písně and Kytice), in which the woman is presented as a permanent character who is in the focus of significant conflict situations and moral problems. Women's words have a broad spectrum of expression: from the intimate address to oneself, through the prayer, the blessing, the divination, and the imprecation, to the prophecy. Women's words refer to a peculiar reflection of the collective memory and norm, but at the same time they bring the woman out of her anonymity, individualizing her in her own desires and intentions.

Keywords: speech of the woman, prayer, blessing, divination, imprecation, collective memory

В поетичните текстове на К.Я. Ербен (сборниците Kytice z pověstí národních, 1853 и Kytice z básní, 1874) ${ }^{1}$ жената присъства като постоянен персонаж, който е във фокуса на значими конфликтни ситуации и морални проблеми. Нейното слово е с широкоспектьрно проявление - от интимното обрьщане към самата себе си, през молитвата, наричането, гадаенето, клетвата до пророчеството. Речта на жената е своеобразно отражение на колективната памет и норма, но в същото време я извежда от анонимност, индивидуализира я в собствените й желания и намерения.

${ }^{1}$ K.J. Erben, Kytice z pověstí národních, 1853, Česká elektronická knihovna <http:// www.ceska-poezie.cz/cek>, 30.07.2012. K.J. Erben, Kytice z básní, 1874, Česká elektronická knihovna <http://www.ceska-poezie.cz/cek/>, 30.07.2012. 
Чрез разнообразните речеви практики в поетичните текстове на Ербен са реализирани различни представи за времето - от гномичното до профетичното, като основна действаща фигура навсякъде е жената. Нейното слово формира конкретното време, успоредно с това тя формира себе си. Така, от една страна, се реализира нейната творческа сила, потвърдена е изконната й способност да създава и съхранява, а от друга, на преден план изпъква въпросът доколко тя познава силата на думите, в каква степен отношението й към тях е плод на традицията. Очертава се възможността посредством собственото слово на жената да надникнем във вътрешния й свят, да осмислим ролята му на механизъм за идентификация на личността. Редица речеви прояви са перформативни актове - в тях словото се превръща в дело, придобива „пльт” в процеса на своята реализация.

В баладите са въведени различни фази от живота на жената - девойките, които се вълнуват от своята съдба (ك̌tědrý den) ${ }^{2}$; момичето, което споделя мъката си по любимия (Svatební košile); разкрити са различни нюанси във взаимоотношенията на майката с нейното дете раздялата и нейното преодоляване (Vrba), необходимостта от осмисляне на тази връзка, от нейното оценностяване (Poklad), необратимостта на загубата (Polednice), разрушаването на връзката (Dčeřina kletba), както и прерастването на тази любов в грижа за целия народ (Věštkyně). Аспектите на релацията майка - дете са видени в рамките на две основни функции на словото - да създава и да разрушава.

В баладата Poklad в думите на жената, пред която се разкрива съкровището, се пресичат няколко смислови пласта. Те имат конкретен прагматичен смисъл, изразяват нейната изненада от видяното, представляват своеобразен опит да се аргументира потребността от богатство в живота на един беден човек. Едновременно с това имат и допълнителен смисъл предвид това, че са произнесени пред отворената земна (или скална) повърхност. В разпространения в Древна Гърция архаичен ритуал на пророкуване оракулът или жрицата на Гея предсказва бъдещето, като най-често е разположен(а) до цепнатина

${ }^{2}$ K.J. Erben, Kytice z pověstí národních, 1853, Česká elektronická knihovna <http:// www.ceska-poezie.cz/cek>, 30.07.2012. Към този сборник принадлежат и разглежданите балади Svatební košile, Vrba, Poklad, Polednice, Dčeřina kletba, Věštkyně. 
в земята. Мирча Елиаде смята, че тази оракулска сила е обвързана със „способността на земята да погльща периодично всички живи създания"3. Тук обаче можем да видим частично реализиран и ритуалът на засяване, при който вместо семе, което да порастне и даде плод, над отворената земя се изричат думи. Човешкото слово и семето са в синонимни отношения - внесени в утробата, която се е отворила, те обезпечават някаква предстояща реалност, оказват се нейно начало и първоизточник.

Случващото се по-нататък в баладата е потвърждение на изреченото от майката - тя казва, че се нуждае от богатството, взема от него, суети се, прави планове за бъдещето, докато загребва с шепи от съкровището, забравя своето дете и го изгубва със затварянето на земните недра. Същата ситуация, но с обратен резултат, наблюдаваме и в момента на отваряне на земната повърхност една година по-късно - жената вижда детето си и отново произнася думи с особен смисъл моли се на Богородица за помощ, благодари на Христос. С тях изразява радостта си от връщането на най-милото й същество.

Начинът, по който майката говори на своето дете в Polednice, преформира отношенията им, разкъсва връзката между тях. Названията „циганин”, „нехранимайко”, „злосторник” хвърлят сянка върху традиционната представа за жената. Тя не изрича нежни думи, за да успокои своето дете, проявява към него особена нетърпимост и грубост, вика Пладницата да го вземе. С нейното идването обаче жената осъзнава реалността на заплахата и прави опит да го спаси. Речевото й присъствие я показва като по-страшна от самото фолклорно демонично същество - то се подчинява на нейната воля да дойде, очевидно разбира силата на думите, докато тя няма съзнание за това. Заслужава внимание фактьт, че майката владее езика на демоните (те я разбират и изпълняват нейните желания), но не успява да докосне с молитвите си Христос. Докато се обръща към Бог, тя прави опит да се покае, но остава в рамките на формулното изповядване („Kriste pane! / odpust' hříchy hřŕšníci” и „Pro Kristovu drahou muku!”), не споделя конкретно свое прегрешение. В текста отсъства внушение за събудената човешка съвест, за осъзнато зло, което героинята да иска да изкупи. Според

${ }^{3}$ М. Елиаде, Трактат по история на религиите, прев. Т. Минева, София 1995 , стр. 288. 
Фром: „Истинското разкаяние и свързаното с него чувство на срам е единствената форма на човешки опит, която може да попречи за повтарянето на вече извършено престьпление". Основните чувства на майката при срещата с Пладница са страх и ужас, а те не помагат на личността да организира обзелия я хаос, не провокират, не задействат висшите сили на съзнанието ${ }^{5}$. Срещата с фолклорното демонично същество е своеобразен отговор на нейната молитва - разкаянието не е достатъчно искрено или е дошло твърде късно, за да предизвика промяна, преподредба на съществуващия ред.

Ролята на изреченото слово в този текст диалогизира с функциите на словото в Dceřina kletba, където инициатор на разговора е дъщерята. Упреците, които девойката отправя към своята майка, са пълни с жестокост и с признание за това колко трудно може да бъде оневинено отклонението от колективните норми. Тук отново словото е провокирано от емоционално състояние. Отправените обвинения не показват героинята като човек, който съзнава извършеното, който се разкайва и е готов да изкупи греховете си. Думите на клетвата са повторени от конкретните дела. Така майката е наказана двукратно - веднъж от упреците на най-близкото си същество, а след това и от предприетите от него действия. Проклятието застига не само онзи, който го изрича, но и най-близките, които страдат за него и споделят съдбата му.

И в двата текста липсва покаянието, човекът не е поставил в центъра на своя свят Бог, не е станал прозрачен, проницаем за Него, в резултат на смирение и осъзнаване на случилото се. Неприетата изповед свидетелства за това, че Христос не стои невидим, не приема за истинно човешкото слово, отхвърля изреченото. В този диалог с обекта на своята вяра човекът не достига до промяна на отношението си, не успява да прозре, че допуснатата грешка, изреченият упрек са насочени не само към ближния, но преди всичко към образа на Бог в себе си. И в двата текста героините се изправят пред откритието за силата на думите - те не са докрай готови да поемат последствията от тяхно-

${ }^{4}$ Е. Фром, Човекът за себе си. Изследване психологията на етиката, прев. С. Кулев, София 1995, стр. 11.

${ }_{5}^{5}$ М. Уваров, Текст как исповедь, в: idem, Архитектоника исповедального слово, Санкт-Петербург 1994, стр. 24. 
то изпълнение. Говорещата жена се оказва несьвършена в своите изконни характеристики - в първия случай тя сама е готова да отхвърли детето си, а във втория жестоките упреци към майката разколебават както нейните качества, така и тези на девойката.

Реализирането на недокрай осъзнатото слово, изпълнението на молитвата дава възможност на човека да постигне желанията си, да види себе си като творец на собствената си съдба. Този мотив е разработван от Ербен и в други текстове, в които не са използвани жанровите възможностите на баладата. В Копнежа на девойката (Тйžba dívč́, Kytice z básní ${ }^{6}$ ) изповедният характер на нейното слово очертава представата за силата на собствената й любов, без да въвежда възможности за изпълнение на изречените обещания. Но и сами по себе си тези заричания са достатъчно силни:

Políbild ho bych v ústa

byt' i vlčí krev měl na nich

stiskla bych mu mile ruku

byt' i držel hada v dlaních.

Този поетичен текст, който по думите на самия автор е инспириран от финландския фолклор, илюстрира сякаш само първата фаза на връзката между двама души, говори за готовността на влюбеното момиче да се срещне с любимия. В него е избягната или все още не е достигната фазата на истинската драматична среща между намерението и неговата реализация. В Svatební košile девойката, която страда за своя възлюбен и го обича толкова, че би дала живота си за него (,život bych dala pro něho"), произнася последователно три молитви. В първата се обръща към Богородица, като твърди, че ако Богородица не й върне милия, по-добре ще бъде да отнеме живота й, във втората и третата търси помощ от Христос и Богородица, за да поправи вече реализираната среща, за да се освободи от любимия и да се спаси. В това обръщане към трансцедентното героинята конституира себе си; назовавайки своите желания, говорейки за онова, което й липсва, тя очертава картината на съществуващото, на изграждащото човека. Изреченото в молитва е своеобразно признание за непостигната

${ }^{6}$ K.J. Erben, Kytice z básní, 1874, Česká elektronická knihovna <http://www.ceskapoezie.cz/cek/>, 30.07.2012. 
цялостност, за липсващо щастие, чиито основания героинята намира извън себе си. Втората и третата молитва възстановяват християнската представа за силата на Христос и Богородица в живота на човека - девойката се моли за закрила, за спасение на душата, за освобождаване от злата сила, която я е подчинила. Както първата, така и тези две молитви са чути. Фолклорно-демоничните сили и тук, както в Polednice, въвеждат една непозната страна, която е провокирана от изреченото и пожеланото от човека. В резултат на непомерните си искания той е изправен пред неочаквани препятствия, които трудно може да преодолее. В различна степен са мобилизирани собствените му възможности и резултатите зависят от силата на неговата вяра. Пророческите думи на девойките в Štědrý den имат за основа славянския ритуал на гадаене в навечерието на Бъдни вечер. В качеството си на преднамерено действие, което има за цел да осигури знание за бъдещето, гадаенето обхваща три важни етапа: подготвителни действия, получаване на съответен знак и неговото тълкуване 7 . Така наречените матримониални гадания имат за цел преминаване отвъд познатото, осигуряват поглед към неизвестното, явяват се ритуално действие, което, от една страна, обезпечава необходимата информация, а от друга, функционира като магическо действие, което реализира желаното. Изборът на езерото като посредник е естествен. Според Виноградова, ,активната роля на водата в гаданията е свързана с осмислянето й като граница между земния и отвъдния свят",

Погледът към водната повърхност е едновременно с това и надникване-оглеждане в собствената си същност. Словото, което девойките изричат, само доизяснява видяната от всяка от тях картина. В тази ситуация обаче двете момичета пропускат да извършат тълкуване, те приемат „наблюдаваното” за безпрекословна истина. Отнет, нереализиран остава моментьт на внасяне на собствен смисъл и възможни значения. Така образът във водните глъбини и представата за себе си се превръщат в едно и също. Посредством оглеждането се създава един пространствен образ на вътрешния свят. Разказът за „видяното” придава плът на безплътното, неговото изричане

7 Л.Н. Виноградова, Гадания, в: еadem, Народная демонология и мифо-ритуальная традичия Славян, Москва 2000, стр. 329.

${ }^{8}$ Ibidem, cтp. 335. 
го превръща в действително. Постигнати са две различни реализации на словото - то е както създаващо, така и отнемащо, убиващо - но този път неговите възможности са реализирани в две отделни човешки съдби. Изреченото слово моделира случващото се с девойките, формира две напълно различни линии, задава двата полюса на съществуването - живота и смъртта. Като особено значими детайли тук са назовани вечерта преди Рождество - „майка на нощите”, фактьт, че действието се извършва в полунощ, а също и предшестващите действия на разсичане с брадва на водната повърхност. Посредством гаданието жената е въведена в ролята на медиатор, чрез нея са свързани този и онзи свят, профанното и сакралното време. Сдвояването на двете възможности - живот и смърт - е представено като напълно естествено, то е продукт и от обвързването им като предстоящи за двете приятелки. Постигнатото знание, докосването до неизвестното не нарушава традиционните представи - напротив, то се вписва в съществуващите норми и ги потвърждава. Като елементи от един естествен процес присъстват тази висока степен на будност по отношение на бъдещето и дрямката на възрастната жена край огнището. В същото време е изказана позицията на лиро-епическия говорител:

Však lépe v mylné naději snít, (...)

nežli budoucnost odhalit,

strašlivou poznat jistotu?

По-добре в измамна надежда да бленуваш, (...)

отколкото да разкриеш бъдещето,

да го познаеш със страшна точност ${ }^{10}$.

Дилемата неизвестност - сигурност поставя въпроса за силата на предопределеността, която тегне над човека, но и за степента, в която той се индивидуализира, когато трябва да я понесе. В същото време се оказва, че двете девойки са изправени пред различни визии за неизвестното - едната поглежда „милия око в око”, а пред другата се „отваря" светът на отвъдното. Различно по своята сила се оказва познанието, което те трябва да понесат.

${ }^{9}$ K.J. Erben, Kytice z pověstí národních, 1853, Česká elektronická knihovna <http:// www.ceska-poezie.cz/cek>, 30.07.2012.

${ }^{10}$ Преводите на поетичните текстове са направени от Таня Маджарова. 
Разговорът на майката с детето има интимен характер, той е говорене за съкровеното. Ако в Poklad цялата баладична линия помага да се стигне до тази съкровеност, да се защити нейния избор, в Polednice тази близост е напълно изгубена. В баладата Vrba дървената люлка поема функциите на женската реч. Така се внушава представата, че споменът за майката не е изгубен, че истината не може да бъде унищожена.

Словото, което убива - това са думите на старата жена във Vrba, която помага на страдащия за своята жена мъж, но едновременно с това донася нейната смърт и оставя без майка малкото дете. С унищожителната сила на словото се срещаме и в Polednice, както и в Dceřina kletba. В тези текстове то е произнесено, за да поправи предшестващи го човешки постъпки. Съотношението слово - дело в тях е дискредитирано, отнети са възможностите на думите там, където човекът вече е предприел конкретни действия - мъжът съжалява, че е отрязал върбата, майката съжалява, че е извикала демоничното същество, дъщерята изрича жестоки думи срещу своята майка, но не може да промени собствения си живот. В стремежа си да изкупят чрез слово своите дела героите не успяват да го постигнат, изречените думи само проясняват случилото се, показват неговата естественост и закономерност.

В ритуалното слово на жената присъстват различни фолклорни жанрове като наричане, гадаене, клетва, пророчество и др. Тяхното въвеждане онагледява срещата на колективното и личното начало. Въпреки че случващото се е предадено най-често като максимално обобщено, типично за фолклорния човек преживяване, той не е изцяло вместен в традицията, не е напълно лишен от избор и позиция. Жената сама избира конкретната речева формула, сама направлява хода на събитията. В нейното слово присъства нормата, но едновременно с това съществуват възможности за дистанциране от нея, за очертаване на собствена линия на поведение.

Героините понасят последствията от изреченото слово, те са „осъдени” да преживеят неговото въплъщаване. Посредством реализацията на желаното, те се изправят пред познание за силата на думите. Ефектът на случилото се им разкрива особената сила, която носят в себе си - да създават, но и да унищожават. Светът на изрече- 
ните думи, аспектите при проявяване на словото повтарят основни, същностни за присъствието на жената черти. Нейният глас се чува, собственото й гномично време задвижва колективното, задава му конкретна насока и параметри. В нейното присъствие прозира архетипен модел на жената, която говори, докато природата се вслушва в нейните желания. За ролята на този проблем свидетелства и конкретното място, което Ербен му отделя в своите „реплики” спрямо Свещеното писание. В Отглас от Псалм 45 (Kytice z básnî) $^{11}$ четем:

Dobré v srdci zrodilo se slovo,

Slovo dobré z úst vychází v jevy;

Jazyk můj co péro pisařovo

O králit' mé vypravují zpěvy.

Вторият стих от този авторски текст липсва в библейския псалм (,Vyneslo srdce mé slovo dobré, vypravovati budu písně své o králi, jazyk můj jako péro hbitého písaře" ${ }^{, 12}$ ). Той очевидно акцентира върху собствения прочит, върху онова разбиране, което внася индивидуални отсенки в смисъла. Очевиден е стремежът да се внесе яснота, да се доразвие съществуваща в текста първоизточник възможност. Обвързани са сърцето, добрите думи и делата, които са техен резултат. Но лирическият говорител не само коментира библейската първооснова и разсъждава над нея, той вмъква скрит цитат от Евангелието от Йоан:

Ale těm, kteří ho přijali,

Dal právo být Božími dětmi -

všem těm, kdo věři v jeho jméno.

Takoví nejsou narozeni z krve,

ani $\mathrm{z}$ vůle těla, ani $\mathrm{z}$ vůle muže,

ale $\mathrm{z}$ Boha.

To Slovo se stalo tělěm

A př́ǐšlo žít mezi nás.

Spatřili jsme jeho slávu,

${ }^{11}$ K.J. Erben, Kytice z básní, 1874, Česká elektronická knihovna <http://www.ceskapoezie.cz/cek/>, 30.07.2012.

${ }^{12}$ Bible kralická. Žalmy, 45:2, <www. elf.cuni.cz>, 30.07.2012. 
slávu, jakou má od Otce jednorozený Syn,

plný milosti a pravdy ${ }^{13}$.

В евангелския текст са откроени не само постьпките на онези, които са повярвали в Бог и са станали негови деца, но и специфичната им роля на избраници, които са познали Христовата милост и истина. Краткият откъс от Отгласа функционира като своеобразен ориентир за изправения пред избор човек, за онзи, който е напуснал границите на колективната норма поради неочакваното въпльщаване на изреченото. Той е своеобразен отговор за онзи, който, боравейки с формулите на колективното знание, е преминал отвъд очакваното, за да се окаже отворен, непредсказуем в динамичното търсене на себе си и своите нови ценности.

${ }^{13}$ Bible. Překlad 21. Století, 1:12-14, Praha 2009. 